\title{
Physicotechnical approach to systemic film moistening
}

\author{
A.V. Blinnikov \\ Institute of Space and Information Technologies of the Siberian Federal University, 26, \\ building 1, st. Academician Kirenskiy, Krasnoyarsk, 660074, Russia \\ Krasnoyarsk State Agrarian University, Prospect Mira, 90, Krasnoyarsk, 660049, Russia \\ Regional Government-Owned Publicly Funded Institution of Culture "Enisey Kino", 153, st. \\ Proletarskaya, Krasnoyarsk, 660100, Russia \\ E-mail: blinshur@yandex.ru
}

\begin{abstract}
This article discusses the features of storage, humidification and operation of film in Central Siberian conditions. A number of features and a certain factology are revealed that affect the organization of systemic moistening (humidification) and maintenance of film materials on analog media for long-term storage and operation of film. The main factors included in the description of this article, which affect the dynamics of maintaining the working surface of $35 \mathrm{~mm}$ and $16 \mathrm{~mm}$ film: the specifics of the composition of the film; the impact of a temporary, natural and technological nature on the "light pictures"; sophisticated technology for servicing analog film projectors, rewinding devices and film checking facilities; the specifics of the sequence of manipulations of equipment and chemical compositions for stable operation without gusts, drying and burnout of film materials. The article shows the content of work on the stages of film moistening, taking into account the specifics of their application. This specificity manifests itself most significantly when working with especially fragile film materials that are of cultural value and have an actual shelf life of at least 60 years. In the step-by-step process of moistening, after the end of each stage, the main results obtained are assessed by visual comparison of the image projections, followed by the digitization of the image and the correction of the result obtained in graphic editors. If the "light picture" is of interest and needs additional adjustments to eliminate artifacts, scratches and other elements of entropy, then neural network approaches are used to work with film material. The article presents an analysis that allows you to determine the permissible option for the implementation of film moistening in the given conditions of film testing for subsequent projection on film equipment.
\end{abstract}

Keywords: motion picture materials, physical and technical methods, film moistening, film residual liquid, isopropyl alcohol, acetone, glycerin 


\title{
Физико-технический подход к системному увлажнению киноплёнки
}

\author{
А.В. Блинников \\ Институт Космических и информационных технологий Сибирского федерального \\ университета, ул. Академика Киренского, 26 к.1, Красноярск, 660074, Россия \\ Красноярский государственный аграрный университет, 90, пр. Мира, Красноярск, \\ 660049, Россия \\ Краевое государственное бюджетное учреждение культуры «Енисей кино», Хранитель \\ фондов отдела хранения и ремонта фильмофонда, 153, ул. Пролетарская, Красноярск, \\ 660100 , Россия \\ E-mail: blinshur@yandex.ru
}

\begin{abstract}
Абстракт. В данной статье рассматриваются особенности хранения, увлажнения и эксплуатации киноплёнки в среднесибирских условиях. Выявляется ряд особенностей и определённая фактология, влияющая на организацию системного увлажнения и поддержания киноматериалов на аналоговых носителях для длительного хранения и эксплуатации киноплёнки. Основные факторы, вошедшие в описание данной статьи, которые влияют на динамику сохранения рабочей поверхности 35 мм и 16 мм плёнки: специфика состава киноплёнки; воздействия временного, природного и технологического характера на «световые картины»; сложная технология обслуживания аналоговых кинопроекторов, перемоточных устройств и средств фильмопроверки; специфика последовательности манипуляций оборудования и химических составов для стабильной работы без порывов, высушивания и выгораний киноматериалов. В статье показано содержание работ по этапам увлажнения киноплёнки, с учетом специфики их применения. Данная специфика наиболее существенно проявляется при работе с особо хрупкими киноматериалами, которые представляют культурную ценность и имеют фактический срок хранения не менее 60 лет. При поэтапном процессе увлажнения после окончания каждого этапа выполняется оценка основных полученных результатов путем визуального сравнения проекций изображения, далее следует оцифровка изображения и корректировка полученного результата в графических редакторах. Если «световая картина» представляет интерес и нуждается в дополнительных корректировках, по устранению артефактов, царапин и прочих элементов энтропии, то применяются уже нейросетевые подходы для работы с киноматериалом. В статье представлен анализ, который позволяет определить допустимый вариант реализации увлажнения киноплёнки в заданных условиях фильмопроверки для последующей проекции на кинооборудовании.
\end{abstract}

Ключевые слова: кинофотоматериалы, физико-технические методы, увлажнение кинопленки, фильмостатная жидкость, изопропиловый спирт, ацетон, глицерин

\section{1. Введение}

Относящиеся к историко-культурным ценностям, охраняемые государством как исторические артефакты и объекты культурного наследия, кинофотоматериалы, как и другие документы государственных архивов, подлежат вечному хранению, которое обеспечивается 


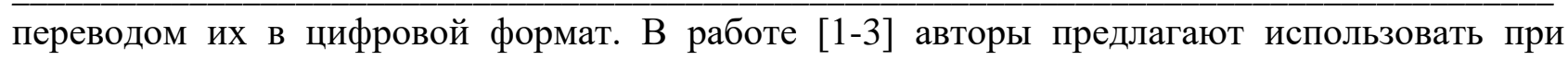
подготовке материалов на эфироцеллюлозной основе к оцифровке для последующего долгосрочного хранения полимерные лаки. Данный способ [2] позволяет существенно снизить трудоемкость корректировки сканированных изображений при их переводе из аналогового формата в цифровой.

\section{2. Исторические аспекты исследования}

Кино в город Красноярск Енисейской губернии пришло буквально через пару лет после знаменитого показа в Париже на Boulevard des Capucines. Первый общественный киносеанс в Енисейской губернии прошел 9 марта 1897 года. Этот показ состоялся в городе Красноярске благодаря коммивояжеру Моржецкому и привезённому анимографу лондонского оптикамеханика Поля, который он собрал по заказу «Северо-Американской компании фонографов» [4]. Но главным первопроходцем кинематографа в Красноярске стал Василий Алексеевич Поляков - начинал он гастролером с киноаппаратом. Чуть позднее, с повсеместным приходом «волшебных фонарей», показывавших «световые картины», стали организовываться склады с фильмокопиями на территории Енисейской губернии, которые периодически уничтожались пожарами, так как киноплёнка в начале века была на нитрооснове и являлась пожароопасным продуктом. В двадцатые годы ХХ-го столетия разрозненные частные склады начали объединять, и к 1935 году в Красноярске уже работал КиноТрест, занимавшийся прокатом кинофильмов на территории Красноярского края.

Фильмофонд КГБУК «Енисей кино» периодически пополняется фильмокопиями, которые порой попадают из самых разных мест: Краевой музей, КИЦ (бывший Музей Ленина, а ныне МЦ «Площадь Мира»), Канский филиал КГБУК «Енисей кино», Минусинский, Ачинский, несколько фильмокопий пришло из «Дома Науки и техники». Не так давно в Красноярск из Норильска по навигационным путям прибыл Северный архив, часто киноплёнки приносят жители города или отравляют на оцифровку с территорий Красноярского края. Киноплёнка встречается самая разная, и цветная, и чёрно-белая, и повреждённая, и выцветшая. И для того, чтобы фильмокопию можно было правильно хранить и в дальнейшем эксплуатировать, надо определить, что же конкретно и в каком состоянии попадает в фильмохранилище.

Если с "узкой" 16-мм киноплёнкой работать достаточно просто и без видимой энтропии (триацетат или диацетат советского производства или ORWO производства ГДР от «Filmfabrik Wolfen» из города Вольфена под Биттерфельдом, или AGFA европейской компании из города Мортсел, Бельгия), то с плёнкой 35 мм возможны серьезные трудности при обработке (см. 
например, ГОСТ 20904-82. Кинопленка 16-мм. размеры и методы контроля и ГОСТ 4896-80. Кинопленка 35-мм. размеры и методы контроля).

Современная киноплёнка на лавсановой основе встречается и с синей циановой фонограммой, и с красно-коричневой фонограммой, и с пурпурной. Подобная фонограмма, кстати, печаталась вплоть до середины нулевых и прекрасно воспроизводится как на советской киноаппаратуре, так и на кинопроекторах иностранного производства [5-7].

Советская киноплёнка производстенного объединения "Свема" (Светочувствительные материалы Шосткинскинского химического комбината), или "Тасма" (Татарские светочувствительные материалы Казанского химзавод им. Куйбышева) на триацетатной основе, как правило, весьма красновата, впрочем, градации красного, насыщенность и тон зависят от года выпуска (менее пурпурная и багряная - плёнка 1985-1989 годов, а самая алая - начала и середины 1990-х годов).

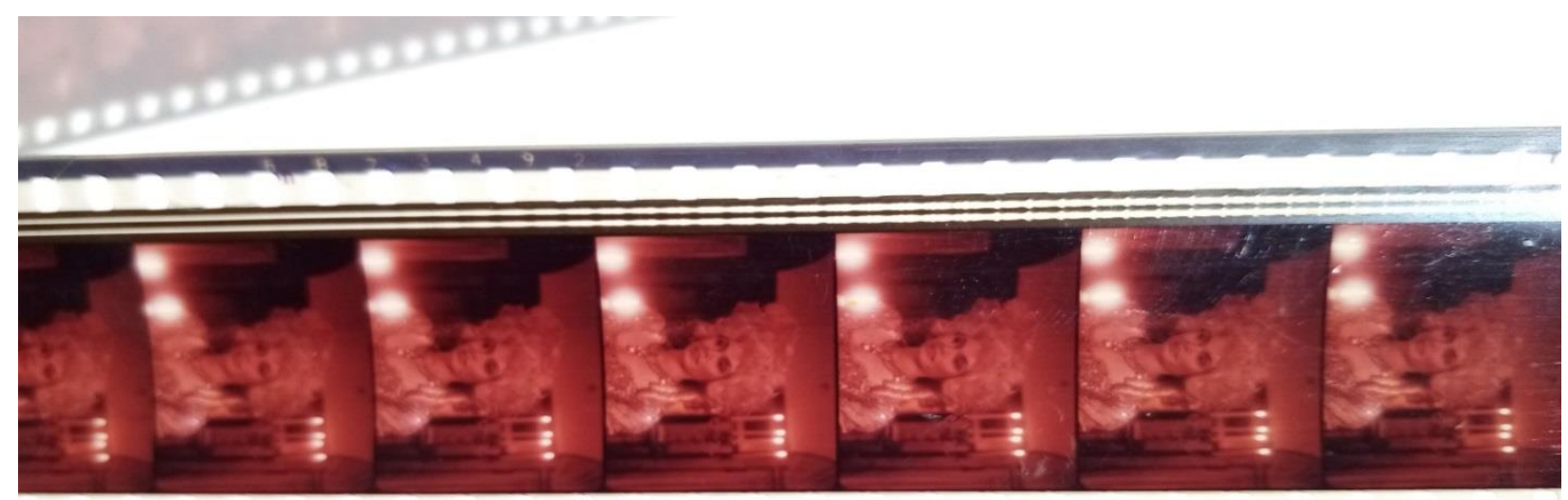

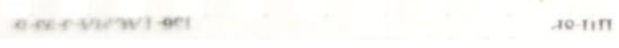

Рисунок 1. Киноплёнка производственного объединения "Свема".

Если копию просматривали и просвечивали в основном на проекторах с ксеноновыми лампами, то фильмокопия, обычно, намного краснее, чем, если, скажем, её смотрели на аппаратуре с лампами накаливания (например, киноустановки КН15, КН15-3, КН16, КН17, КН17М, КН19П, КН20П, КН20, КН20А и др.) [6].

Также триацетатная плёнка очень быстро может пересыхать, становясь при этом и ломкой, и нестабильной на сгибах и перфорациях, поэтому именно триацетатная кинолента требует особых условий хранения: температура не выше +20 , влажность не менее $60 \%$. В условиях фильмо-склада создать подобные условия хранения достаточно сложно, так как основная система отопления монтировалась в 80-е годы, поэтому триацетатная киноплёнка хранится в наиболее прохладном и хотя бы относительно сухом и проветриваемом помещении 
(в закрытых частёвых банках под 35 мм, чтобы пленка не пересыхала, и не находилась ни на солнце, ни рядом с конвекторами).

При сложных условиях хранения с высокой температурой, низкой влажностью, при хранении киноплёнки без жестяных коробок, либо не в яуфах или частёвках кинолента пересыхает, становится хрупкой, легко рвётся и деформируется. Так же из-за усадки плёнки, лента в лентопротяжном механизме проектора перестаёт нормально двигаться, в следствии чего, из-за уменьшения шага перфорации возникают проблемы с зацепление транспортирующими зубчатыми деталями, грейферным или мальтийским механизмом.

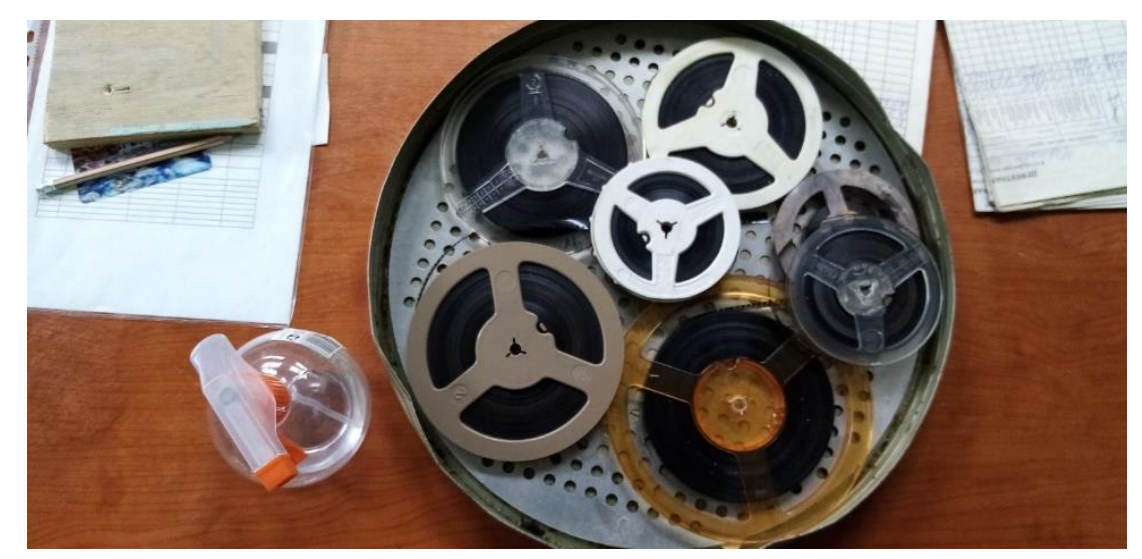

Рисунок 2. Хранение триацетатной пленки 8 мм.

Особенно это относится к 8 мм плёнке, имеющей края с перфорацией 8 мм или «8 Супер» (площадь кадра «8 Супер» увеличена за счёт уменьшения размеров перфорации и увеличения шага кадра до 4,23 мм). Требования представлены в ГОСТ 8761-75. Кинопленка 8-мм. размеры, методы контроля. Перфорационные отверстия размером 0,92×1,14 мм расположены длинной стороной вдоль киноплёнки, а не поперёк, как в стандартном формате 8 мм, и они очень часто повреждаются и рвутся.

Далее рассмотрим вопросы хранения и повреждений 35 мм киноплёнки (рисунок 3).

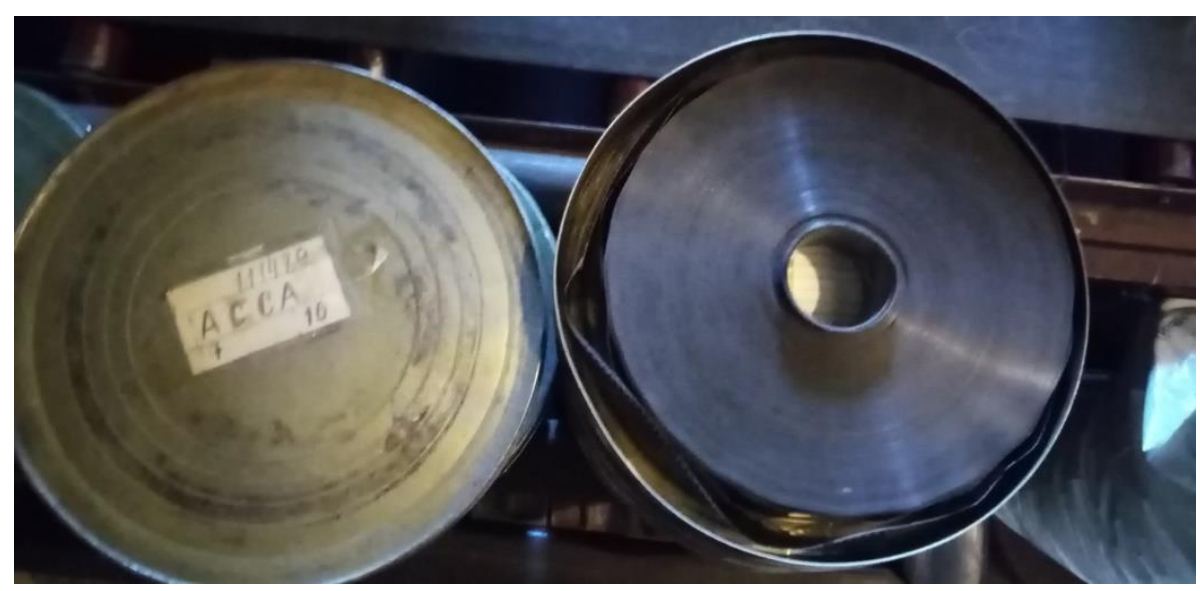

Рисунок 3. Хранение 35 мм кинопленки. 
Во время хранения кинопленок, в том числе и обработанных, начинается усадка, причем на величину усадки сильно влияют характер упаковки рулонов, плотность намотки, температура и влажность в помещении. Иногда происходит удлинение продольных размеров кинопленки, например, при растяжении во время обработки в проявочных машинах.

Под временными изменениями размеров кинопленок понимают усадку или удлинение вследствие влияния влажности окружающего воздуха. Изменение влажности воздуха на $1 \%$ вызывает почти вдвое большее изменение размеров по сравнению с колебаниями по температуре на $1^{\circ} \mathrm{C}$, однако эти процессы обратимы.

По ГОСТу 19-62-76 кинопленки должны храниться при температуре воздуха $50 \pm 5^{\circ}$ и относительной влажности $60 \pm 10 \%$-до 15 суток; при температуре $20+2-5^{\circ} \mathrm{C}$ и относительной влажности $60+5-10 \%$-До одного года; при температуре $15 \pm 5^{\circ}$ и относительной влажности $50+15-10 \%$-до трех лет; с температурой $10 \pm \pm 5^{\circ} \mathrm{C}$ и относительной влажности $50+10 \%$ — свыше трех лет.

Перед передачей на склад на хранение кинопленки наматывают на стандартные «бабышки» фотографическим слоем наружу и укладывают в металлические или другие специальные коробки. Хранят их на стеллажах или в металлических шкафах в горизонтальном положении (рисунок 4).

Температурно-влажностный режим хранения кинопленок контролируется с помощью психрометров не реже одного раза в сутки.

В работе [8] выполнен анализ зацепления зубьев барабана с перфорацией (методическое пособие по кинопоказу). Показано зацепление зубьев барабана и перфораций у нормальной киноплёнки. В этом случае все перфорации стабильно работают, усилие распределяется равномерно. Также представлено зацепление пересохшей киноплёнки с повышенной усадкой. Продемонстрировано, что в этом случае работает только нижняя перфорация, остальные проскальзывают или точнее пропускаются механизмом и, как следствие, повышается износ киноплёнки, разрывы перфораций и частые склейки ленты.

\section{3. Методы работы со «световыми картинами»}

По каким признакам можно определить, что киноплёнку пора увлажнять? Как узнать, что та или иная фильмокопия требует повышенного внимания и определённых манипуляций по восстановлению?

Ответы на эти вопросы можно получить уже после простого визуального осмотра частёвки. Иногда применяется дополнительное оборудование, как например, специальная кинолупа с оптической двойной линзой для увеличения кадра.

Основные признаки того, что пленку уже «пора увлажнять» следующие: 


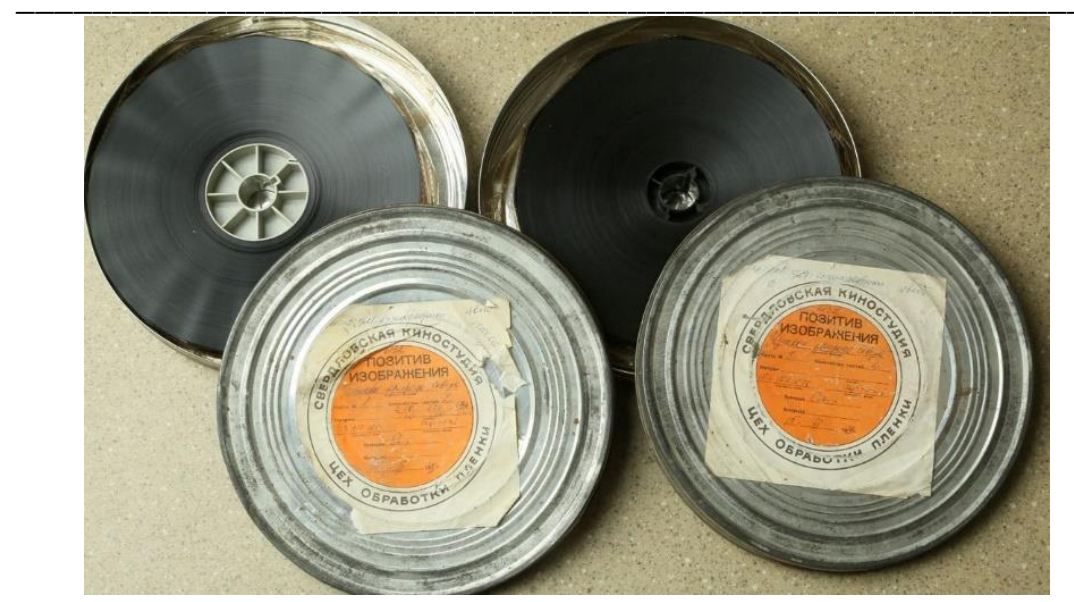

Рисунок 4. Хранение пленки в металлических или других специальных коробках.

- Плёнка очень ломкая, может легко порваться даже от небольшого усилия, рулон частёвки не круглый, а вывернут многоугольником с почти равными гранями (см. рисунок 4);

- Фильм нестабильно скользит в проекторе, заметны горизонтальные скачки и прыжки изображения на киноэкране, появляется повышенный шум и энтропия в виде полос и дефектов при проекции, случается, что плёнка соскакивает с зубчатых барабанов и приходится заряжать её повторно в проектор;

- В процессе склеивания плёнку трудно одеть на зубья пресса. Или часто при попытке сделать склейку повреждаются кромки одетых на зубья перфораций.

Увлажнение существенно помогает восстановить качество киноплёнки. Пересохшую киноленту практически всегда можно попытаться сделать рабочей с помощью увлажнения спецсоставом, однако испорченную неправильным увлажнением плёнку спасти уже будет весьма затруднительно, поэтому надо тщательно соблюдать регламент процесса увлажнения. Очевидно, что увлажнение, это всегда риск, но оправданный риск, если использовать работы выполняются опытными фильмопроверщиками.

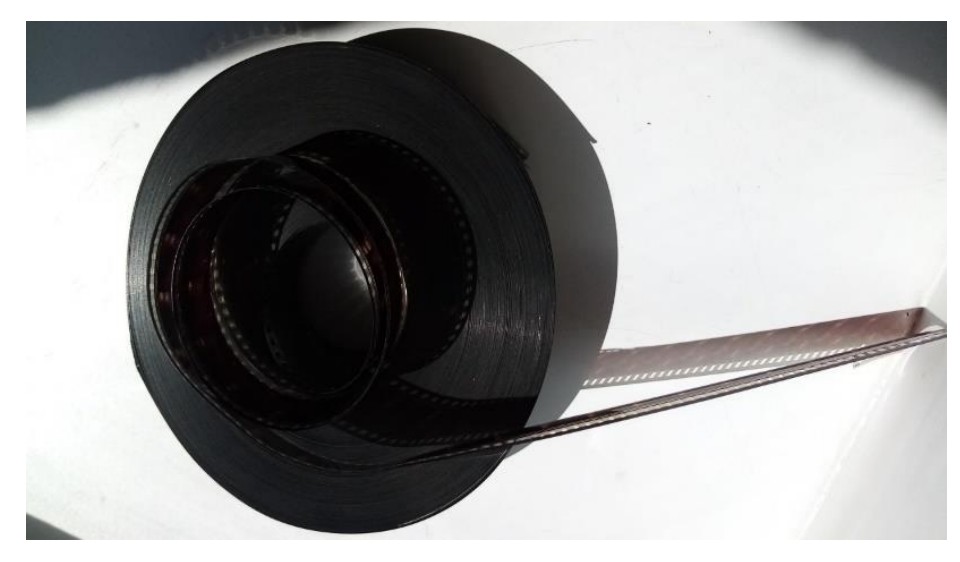

Рисунок 5. Кинопленка в специальной увлажнительной камере. 
Для увлажнения кинопленок их помещают в специальные увлажнительные камеры (гидростаты) или особые шкафы-увлажнители (рисунок 5). Эта операция проводится при температуре $15-20^{\circ} \mathrm{C}$ и относительной влажности $75-85 \%$. Увлажняемые кинопленки должны иметь слабую намотку фотографическим слоем наружу. Для увлажнения применяют насыщенные растворы хлористого натрия или бромистого калия. Продолжительность увлажнения 2-6 суток в зависимости от толщины фотографического слоя и степени пересушивания.

\section{4. Способы и результаты увлажнения киноплёнки}

Для увлажнения киноплёнки в КГБУК «Енисей кино» фильмопроверщиками используется несколько составов: на основе глицерина и ацетона и глицерина с применением изопропилового спирта.

Процентное соотношение увлажняющей (фильмостатной) жидкости № 1:
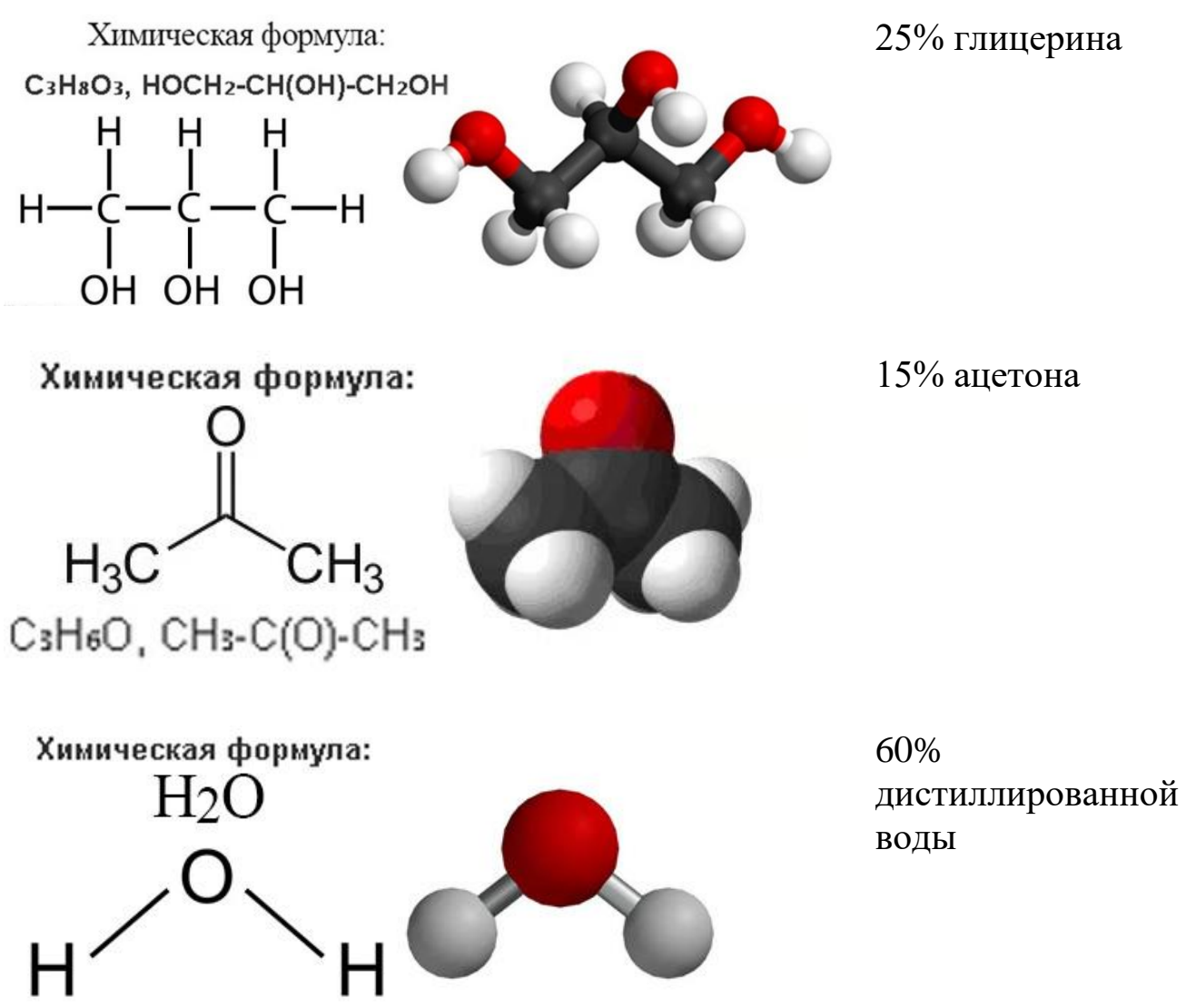

Рисунок 6. Химический состав № 1. 
Процентное соотношение увлажняющей (фильмостатной) жидкости № 2:

Химическая формула:

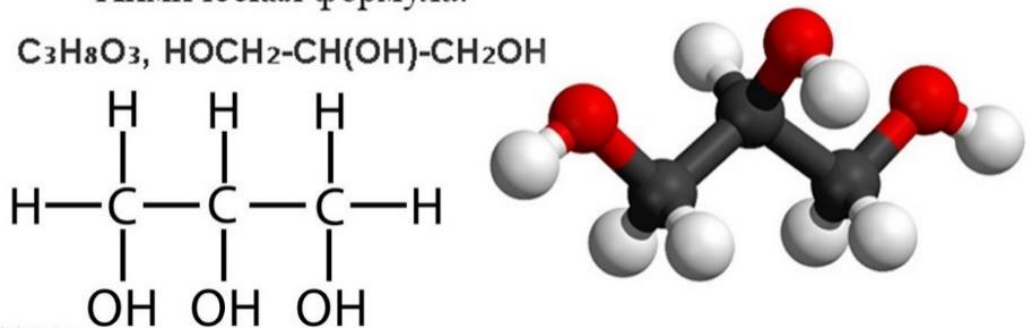

\section{${ }_{2} \mathrm{OH}$}

$40 \%$ глицерина
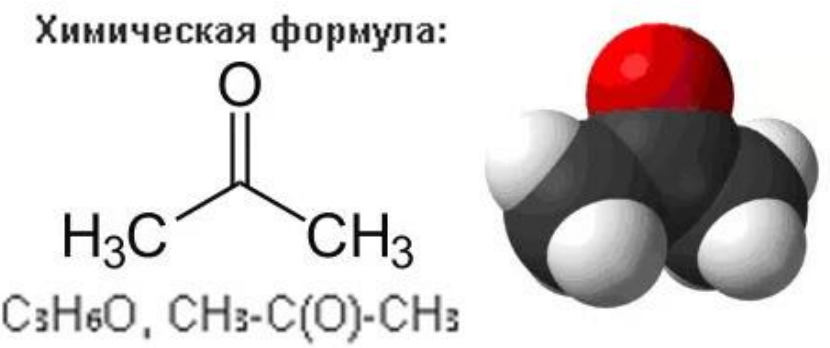

$13 \%$ изопропилового спирта,
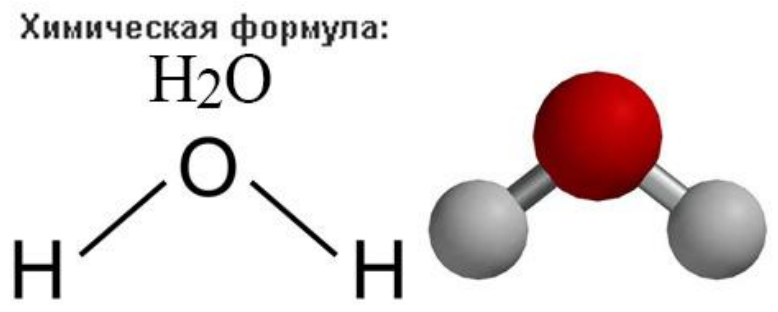

47\% дистиллированной воды.

Рисунок 7. Химический состав № 2.

Продолжительность увлажнения — до двух суток.

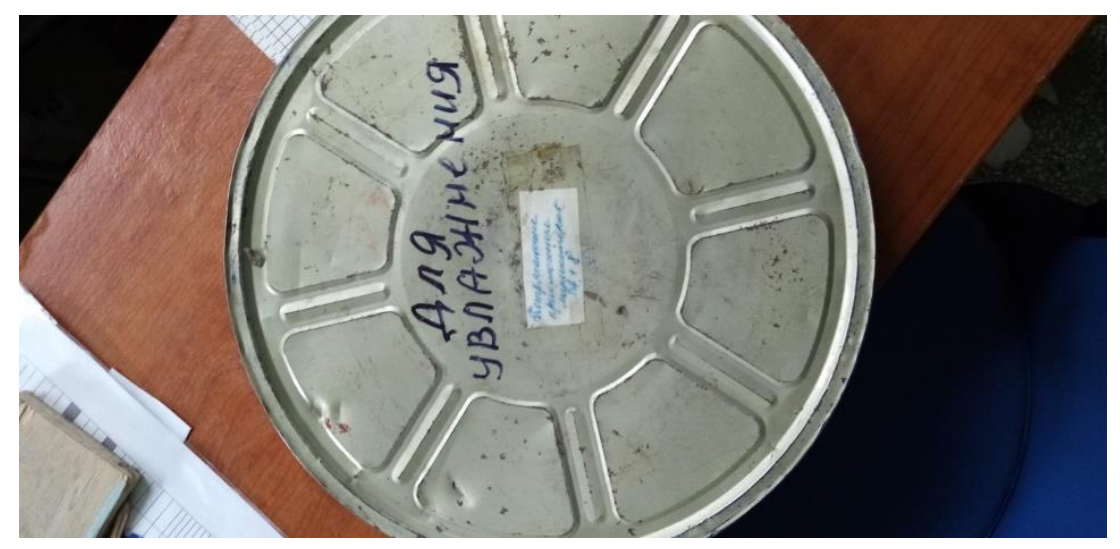

Рисунок 8. Кинопленка в частёвой банке для увлажнения.

Внутрь обычной частёвой банки закладывается увлажняющий элемент - обычно это прокладка из пористого материала, например: сукно, войлок, хлопчатобумажная ткань, картон и пр.), которая смачивается фильмостатной жидкостью. 


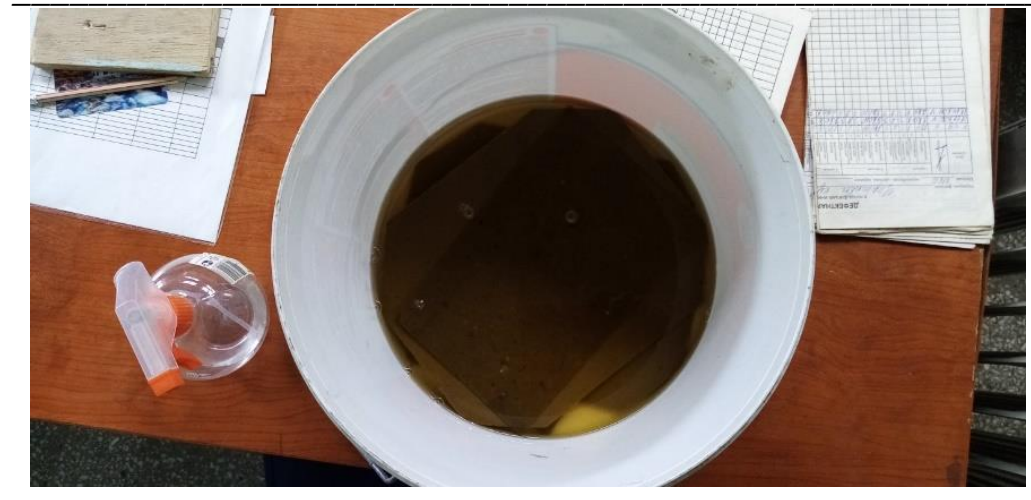

Рисунок 9. Раствор фильмостатной жидкости.

Сверху кладётся алюминиевый диск с отверстиями-перфорациями диаметром 7 мм. (см. рисунок 10).

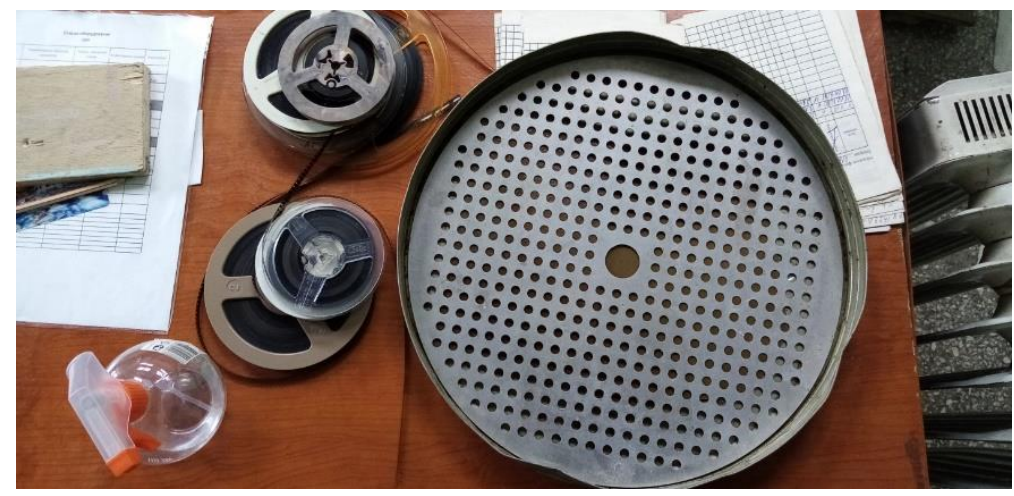

Рисунок 10. Алюминиевый диск с отверстиями-перфорациями.

Затем сверху кладётся рулон киноплёнки. Киноплёнка не должна соприкасаться напрямую с увлажняющей жидкостью и прокладкой, то есть на плёнку не должна попасть ни одна капля фильмостатной жидкости. Результат подобного соприкосновения - это склеивание рулона киноплёнки и такую ленту нужно будет, скорее всего, утилизировать. Прежде чем укладывать киноплёнку, алюминиевый диск желательно немного придавить к прокладке, и посмотреть - не выступит ли через отверстия фильмостатная жидкость. При условии выхода увлажняющего состава через перфорации, лишнюю жидкость удаляют, а диск протирают.

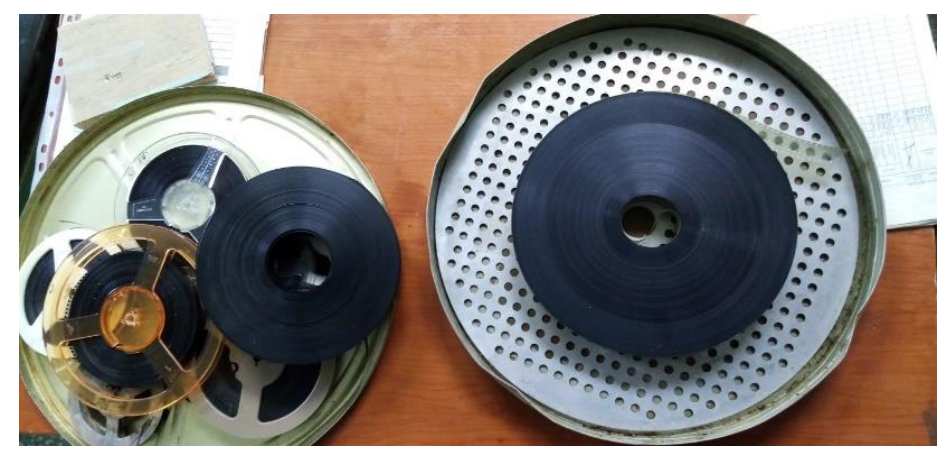

По рекомендациям специалистов рулоны кинопленки полезно упаковывать в
Рисунок 11. Размещение кинопленки для увлажнения. полиэтиленовые пакеты толщиной 0,12 мм и более, так как тонкий полиэтилен гигроскопичен. Размеры пакетов должны быть такими, чтобы почти не оставалось свободного места после (1) 


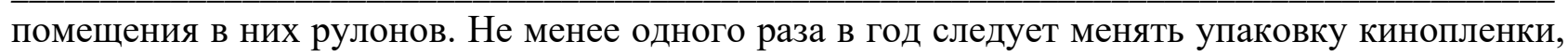
перекладывая ее в новые пакеты в условиях, исключающих конденсацию влаги. Иногда кинопленки рекомендуют помещать в вакуум, в инертные газы или создавать другие специальные условия. Однако на практике достаточно поместить плёнку в жестяную банку частёвок.

Если плёнка десятилетиями хранилась в слишком сыром помещении, то на ней часто появляется плесень. Тогда обрабатывать плёнку следует уже фунгицидными растворами на специальных машинах. Для восстановления утраченных свойств поврежденных негативов, контратипов, промежуточных позитивов и для их очистки и приведения к первоначальному (или близкому к первоначальному виду) применяют уже реставрационную обработку. В частности, среди экспонатов «Музея кино» в КГБУК «Енисей кино» представлена фильмореставрационная машина RT-3 производства ГДР, предназначенная для устранения механических повреждений (царапин и потёртостей) на подложке киноплёнки, возникающих при многократных демонстрациях фильма. Основные узлы машины: лентопротяжный механизм, стеклянный или металлический барабан и сушильная камера. Для устранения повреждений обрабатываемая киноплёнка с обеих сторон чистится с помощью, например, четырёххлористого углерода, промывается, затем полируется замшевыми дисками под водяным душем и поступает в сушильную камеру, где и удаляются остатки влаги.

\section{5. Заключение}

В дореволюционные времена кинофильмы и киноплёнку в нашей стране называли «световыми картинами». А кинопроекторы и оборудование, позволявшее показывать кино «волшебными фонарями». Очевидно, что без увлажнения спецрастворами эти киноплёнки (световые картины) не сохранились бы до настоящего времени. На сегодняшний день на фильмобазе КГБУК «Енисей кино» хранится более 5000 фильмокопий как художественного содержания, так и документального. По кинокартинам, находящимся в фильмохранилище, можно изучать не только хронологию и историю нашей Родины и мира в целом, но также и технологии, и методологии, использовавшиеся в жизни человечества на протяжении, как минимум, последних 120 лет.

Существующие способы увлажнения кинопленки, представленные в данной работе, позволяют сохранить материал в состоянии, когда к нему можно применить новые подходы, развивающиеся на основе цифровых технологий. На сегодняшний день важно, с учетом развития технологий, применения методов искусственного интеллекта, нейросетевых подходов при обработке изображений цифровыми и квантовыми методами [9-11] не растерять опыт, приобретённый за долгие десятилетия работы в фильмопроверочном направлении. 
Именно эти наработки и устоявшиеся рабочие методы по «ухаживанию» за аналоговыми носителями обеспечивают сегодня возможность эффективного сканирования и цифровизации исторического наследия, доставшегося нам от предыдущих поколений.

\section{Список литературы}

[1] Бабкин, О.Э. Реставрация архивных кинофотодокументов: фото- и кинопленки / О.Э. Бабкин, В.В. Ильина // Манускрипт. - 2016. - № 12-1(74). - С. 17-20.

[2] Бабкин, О.Э. Лаки УФ-отверждения / О.Э. Бабкин, Л.А. Бабкина // Лакокрасочные материалы и их применение. - 2009. - № 5. - С. 33-35.

[3] Бабкин, О.Э. Покрытия ультрафиолетового отверждения для функциональной защиты / О.Э. Бабкин , В.В. Бабкина Л.А. Сиротинина // Журн. прикл. химии. - 2016. - Т. 89. № 1. - C. 83-89.

[4] Глебова, И.С. Развитие экранных искусств и их влияние на аудиовизуальное образование (на примере американских киношкол) / И.С. Глебова // Наука телевидения. - 2017. - № 13.3. - C. 33-42.

[5] Фотокинотехника: Энциклопедия / Гл. ред. Иосиф Е. А.; [Предисл. В. Ю. Торчкова]. М.: Сов. энциклопедия, 1981. - 447 с.

[6] Черкасов, Ю.П. Справочник киномеханика: Учеб. пособие для средних проф.-техн. Училищ / Ю.П. Черкасов. - М.: Высшая школа, 1979, второе издание, 325 с.

[7] Данилов, К.Б. Кинопроекция / К.Б. Данилов. - М.: Искусство, 1979. - 144 с. ил. - (Б-ка киномеханика).

[8] Иосиф, Е.А. Кинопленки и их обработка / Е.А. Иосиф. - М.: Искусство, 1964. - 300 с.

[9] Карнаухов, В.Н. Принципы построения цифрового фотоархива российской академии наук / В.Н. Карнаухов, Н.А. Кузнецов, Н.С. Мерзляков, Л.И. Рубанов // Компьютерная оптика. - 1999. - № 19. - С. 188-192.

[10] Дударов, Д.А. Методы обработки цифровых телевизионных сигналов / Д.А. Дударов // Известия Южного федерального университета. Технические науки. - 2004. - № 1(36). - C. 34 .

[11] Байбикова, Т.Н. Комплексы программ для цифровой обработки изображений / Т.Н. Байбикова // Вестник Московского финансово-юридического университета. 2016. - №2. - C. 255-266. 